\title{
Impact of Spirulina on Propylthiouracil - Induced Hypothyroidism in Albino Rats, A Histological, Immunohistochemical and Biochemical Approach
}

Article

\author{
Hala G. EL-Tantawi and Faten S. Abozeid
}

Department of Zoology, Faculty of Science, Ain Shams University, Egypt

\begin{abstract}
Background: Hypothyroidism is a decrease in the production of the thyroid hormones and leads to gland dysfunction. Spirulina used as an antioxidant and supposed as antihypothyroidic agent.

Objective: This study was carried out to investigate the impact of Spirulina on PTU-induced hypothyroidism in rats.

Materials and Methods: The rats were divided into six groups, control group (G1), hypothyroid group (G2), SP-500 treated group (G3), SP-1000 treated group (G4), PTU+SP-500 treated group (G5) and PTU+SP-1000 treated group (G6). Thyroid gland was examined using biochemical, histological, and immunohistochemical studies. Duration of treatments were for 14 days.

Results: A significant decline in the body weight gain was exhibited. Biochemically, a significant decrease in T3 and T4 hormone levels in the PTU-group and a substantial increase in groups treated with Spirulina alone. While PTU+ Spirulina treated groups revealed normal hormonal levels more or less similar to the control group. Histological changes such as congestion of the blood capillaries, follicular dilatation, and vacuolar degeneration of some follicular cells were exhibited in hypothyroid group G2 and Spirulina treated-groups (G3andG4). Hyperplastic cells with hyperchromatic nuclei, depleted vacuolated-thyroglobulin, and a significant increase in the epithelial heights and the follicular diameters, were observed. Immunohistochemically, low expression of the proliferative cellular marker KI-67 was expressed in the PTU and PTU+Spirulina treated groups. While negative expression of KI-67 in Spirulina treated groups was recorded.

Conclusion: Administration of Spirulina alone displayed signs of hyperactivity on the thyroid gland, but it has a mild protective role in the PTU-induced hypothyroidism groups. Therefore, caution should be used in extrapolating these results to the human being situation within different doses and durations.
\end{abstract}

Received: 29 August 2019, Accepted: 22 September 2019

Key Words: Histological changes; hypothyroidism; PTU; KI-67; spirulina.

Corresponding Author: Hala G. EL-Tantawi, PhD, Department of Zoology, Faculty of Science, Ain Shams University, P.O. Box 11566, Abbassia Cairo, Egypt, Tel.: +20 1114687708, E-mail: halaeltantawi@hotmail.com

ISSN: 1110-0559, Vol. 42, No. 4

\section{INTRODUCTION}

The thyroid gland is one of the important endocrine glands that play an essential vital role in the metabolism and energy expense in the body ${ }^{[1]}$. This gland is responsible for production, storage, and releasing of the thyroid hormones triiodothyronine (T3) and thyroxine (T4) ${ }^{[2]}$. Quantitively, (T4) is the predominant hormone, while (T3) is biologically more active and arises from the peripheral deiodination of $\mathrm{T} 4^{[3 a n d 4]}$. The thyroid hormones have a necessary role in controlling and keep on the proper developmental and physiological functions ${ }^{[5]}$. Also, an adequate supply of Iodine is necessary for the regular production of the thyroid hormones ${ }^{[6]}$. Hypothalamus-pituitary-thyroid axis regulates the biosynthesis and secretion of the thyroid hormones. So, the dysfunction of this axis results in an abnormal state, which is exhibited as either hyper- or hyposecretion of hormones that impacted the human body health ${ }^{[7 a n d 8]}$.

Hypothyroidism is a clinical condition that is one of the most common thyroid diseases. In the hypothyroidism, high level of thyroid-stimulating hormone (TSH) are recorded and hyperstimulation of the follicular cells that lead to the changes in the metabolism due to the low production of T3 and T4 ${ }^{[9,10 a n d 11]}$. Propylthiouracil is recorded as one of the drugs that induce the hypothyroidism ${ }^{[12-14]}$. Propylthiouracil (six-n-propyl-2-thiouracil) (PTU) is a thiocarbamidederived drug used as an anti-thyroid agent ${ }^{[15]}$. PTU is considered as one of the vital agents who can initiate hypothyroidism by reducing circulating levels of $\mathrm{T} 3$ and T4 and increasing levels of TSH by inhibition of hypoperoxidase as well as peripheral deiodinase ${ }^{[16]}$.

Spirulina (Arthrospira) is a spiral blue-green microalga belonging to the class of cyanobacteria ${ }^{[17-21]}$. The term of Spirulina represents the dry biomass of the genus Arthrospira sp. ${ }^{[22]}$. Spirulina is a rich source of phycocyanin, carotenoids, biliprotein pigment, proteins, phenolic acids, iodine, and vitamins ${ }^{[23]}$. Moreover, the high active ingredient of C-phycocyanin in spirulina makes it exhibit activities such as an anti-inflammatory, antioxidant; immunomodulatory, hepatoprotective, nephroprotective, neuroprotective, antidiabetic, antigenotoxic, antitoxic, 
antihypertensive and anticancer ${ }^{[24-30]}$. Due to such biological properties about Spirulina, the current study was designed to examine for the first time the ameliorative potential of this alga against the hypothyroidism induced by PTU in albino rats.

\section{MATERIALS AND METHODS}

\section{Chemicals}

Spirulina tablets were purchased from Puritan's Pride Company, Inc. (USA). Each tablet contains $500 \mathrm{mg}$ of the active ingredient. The drug is ground and administered orally in the form of a suspension in $0.9 \%$ saline. Propylthiouracil is available under the name of Thyrocil ${ }^{\circledR}$ (Amoun Pharmaceutical Co., Egypt) as white discoid tablets containing $50 \mathrm{mg}$ of the active ingredient.

\section{Laboratory animals}

Forty-two healthy adult male Wistar albino rats (Rattus norvegicus) weighing 120-140g, were obtained from the Medical Research Center at the Faculty of Medicine, Ain Shams University (Cairo, Egypt). The rats were transported to the animal care unit at the Zoology Department, Faculty of Science, Ain Shams University, two weeks before the starting of the experiment for acclimatization to laboratory conditions. The animals were reared in clean and adequately ventilated cages and bedded on fresh wood shavings. A temperature of $25^{\circ} \mathrm{C}$ and a $12 \mathrm{~h} \mathrm{light/dark} \mathrm{cycle}$ maintained. Free access to water and standard rodent food pellets were available to the animals. All efforts were made to minimize animal suffering and to use only the number of animals necessary to produce reliable scientific data. All animal experiments comply with the National Institutes of Health guide for the care and use of Laboratory Animals (NIH Publications No. 8023, revised 1985), and the experimental protocol was approved by the Ain Shams University Research Ethics Committee.

\section{Experimental design}

Rats were divided into six groups, each of 7 rats, as follows: The control group $(\mathrm{G} 1)$ : rats ingested saline solution. PTU-group (G2): rats treated orally with $50 \mathrm{mg} /$ kg body Wt./day of Propylthiouracil. SP-500 (G3): rats were administered oral dose $500 \mathrm{mg} / \mathrm{kg}$ body $\mathrm{Wt}$./day of Spirulina. SP-1000 (G4): rats treated orally with 1000 $\mathrm{mg} / \mathrm{kg}$ body Wt./day of Spirulina. PTU+ SP-500 (G5): rats were administered oral dose $50 \mathrm{mg} / \mathrm{kg}$ body Wt./ day of Propylthiouracil and $500 \mathrm{mg} / \mathrm{kg}$ body Wt./day of Spirulina.PTU+SP-1000 (G6): rats treated orally with 50 $\mathrm{mg} / \mathrm{kg}$ body Wt./day of Propylthiouracil and $1000 \mathrm{mg} / \mathrm{kg}$ body Wt./day of Spirulina. The treatments were achieved orally by using a gastric tube for the period of 14 days. In the co-administrated groups, the Spirulina was given first, and then after 1 hour, the Propylthiouracil drug was administered.

\section{Sample collection}

At the end of the experiment, the rats were weighed, anesthetized using chloroform, and then necropsied. Blood samples were taken from the heart puncture and centrifuged. The supernatant serum was divided into equal amounts (approximately $200 \mu \mathrm{l}$ ) and frozen at -80 until being assayed for T3, T4, and TSH. The thyroid glands were isolated from the surrounding tissue and processed for the histological examination.

\section{Histological procedures}

Thyroid gland samples were fixed in $10 \%$ formalin solution at room temperature for $24 \mathrm{~h}$. Samples were then dehydrated in ascending grades of ethyl alcohol, cleared in terpineol and embedded in paraffin wax. Paraffin sections $5 \mu \mathrm{m}$ thick were stained with Hematoxylin and Eosin. Photomicrographs were taken using a camera attached to a Leica DM LS2 microscope (Leica Microsystems, Wetzlar, Germany) at the Regional Center for Mycology and Biotechnology, El-Azhar University.

\section{Immunohistochemistry}

In El- Demerdash Hospital, Immunohistochemistry laboratory detection of Ki-67 marker for cellular proliferation was carried out. The tissues were fixed in $10 \%$ formalin, dehydrated, cleared, and then embedded in paraffin. Sections of $5 \mu \mathrm{m}$ were deparaffinized and hydrated in ascending series of alcohols. The tissue sections were incubated with $3 \% \mathrm{H}_{2} \mathrm{O}_{2}$ solution for $20 \mathrm{~min}$ at $27^{\circ} \mathrm{C}$. Then incubated with standard goat serum working solution (Biosharp, Hefei, China) for $30 \mathrm{~min}$ at $27^{\circ} \mathrm{C}$. Next, the sections were incubated overnight at $4{ }^{\circ} \mathrm{C}$ with mouse monoclonal Ki-67 antibody (dilution, 1:500; cat. no. WH0004288M1) from Sigma (St. Louis, MO, USA). Goat anti-mouse IgG secondary polyclonal antibodies (dilution, 1:1,000; cat. no. ab6789; Abcam, Cambridge, MA, USA) were used next for incubation at $27^{\circ} \mathrm{C}$ for 20 $\mathrm{min}$. Finally, the sections were incubated with horse-radish peroxidase-labeled streptavidin working solution at $27^{\circ} \mathrm{C}$ for $20 \mathrm{~min}$. The sections were washed with PBS 3 times, each for $5 \mathrm{~min}$, and DAB solution was added. The sections were counterstained with hematoxylin to stain nuclei, dehydrated, cleared in xylene and mounted with DPX. The sections were examined and photographed using a camera attached to a Leica DM LS2 microscope (Leica Microsystems, Wetzlar, Germany) at the Regional Center for Mycology and Biotechnology, El-Azhar University.

\section{Morphometric measurements}

The image analysis system (Leica Q 500 MC program) at the Regional Center for Mycology and Biotechnology, El-Azhar University, was used to measure:1- The height of the follicular epithelium in HandE-stained slides. 2- The follicular diameter in HandE-stained-slides. Five different nonoverlapping microscopic fields from each specimen in every studied group were examined for the parameters mentioned earlier at a magnification of X 40 .

\section{Hormonal assays}

Serum triiodothyronine (T3), thyroxine (T4), and 
thyroid-stimulating hormone (TSH) were measured by electrochemiluminescence immunoassay on a Cobas ${ }^{\circledR}$ e601 immunoassay analyzer (Roche-Hitachi Diagnostics, Mannheim, Germany). The hormones were assessed according to manufacturer's instructions using commercially available kits from Biodiagnostics (Cairo, Egypt).

\section{Statistical analysis}

Mean values and the standard error reported as numerical data. GraphPad Prism (version 5.0, GraphPad Software, San Diego, CA, USA) was used to conduct all statistical analysis. Data were analyzed statistically using one-way ANOVA followed by post hoc multiple comparisons (Tukey's test) for a comparative study between the groups. $P<0.05$ was regarded as statistically significant.

\section{RESULTS}

\section{Bodyweight}

The rats treated with the different doses of Spirulina or PTU revealed a significant decrease in their body weight gain in comparison to that of the control rats (Table 1). Moreover, a significant decrease in body weight gain was shown in the PTU-group treated with the different doses of Spirulina compared to the PTU-group alone, and this decrease has become dose-dependent. A loss of appetite during the experiment, as well as decreased-locomotor activities was observed in all groups except the control group.

\section{Hormonal results}

Results of the thyroid hormones' level (T3, T4, and TSH) of the control group are represented in (Table 2). Treatment of rats with the different doses of Spirulina revealed more or less similar hormone levels as those of the control group (Table 2), and after PTU treatment, level of T3 and T4 in circulation was significantly decreased, while the level of TSH increased significantly compared to the control group. Whereas the treatment of PTU-group with the different doses of Spirulina exhibited an improvement in the level of the hormones, but this improvement was insignificant and related to the proposed doses.

\section{Morphometric results}

Moderate enlargement of the thyroid gland was revealed in all experimental groups compared to the control group. The gland was firm in texture and darker in color than that in control. The morphometric measurements of the thyroid follicles' diameters and heights of the cubical epithelial cells of the control group were recorded in (Table 3). It is clear that the follicular diameter significantly increased in the treated groups with the different doses of Spirulina, while the epithelial height was insignificantly increased in the low dose of Spirulina and increased dramatically in a high dose of spirulina compared to the control group. In the PTU-group, there was a significant increase in the morphometry of these parameters compared to the control group. On the other hand, the treatment of PTU-group with the different doses of Spirulina hasn't revealed any remarkable change in these measurements compared to the corresponding PTU-group.

\section{Histological results}

Tissue sections of the thyroid gland of the control group (G1) showed well-formed, tightly packed follicles separated by narrow interfollicular tissue, which contains connective tissues with blood capillaries and clusters of interfollicular cells (Figure 1A). The thyroid follicles are variable in size and shapes, filled with a homogeneous acidophilic colloidal substance with the peripherally fine vacuolated regions. The follicles are lined by a single layer of low cuboidal cells having rounded nuclei (Figure 1B).

There were many histopathological changes in all treated groups. Thyroid tissue of the induced hypothyroid group (G2) showed less well-rounded thyroid parenchyma (Figure 2A). The thyroid follicles were disorganized with irregular follicular walls and highly congested blood capillaries. The thyroid follicles appeared with empty lumina, lined mostly with high cuboidal cells containing hyperchromatic nuclei. Some of the follicular cells exhibited apparent cytoplasmic vacuolation. Also, Both follicular cells and the interfollicular cells revealed moderate hyperplasia (Figure 2B).

The histological examination of the thyroid gland tissue sections of groups that were treated with two different doses of Spirulina; the low dose-treated group (G3) and the high dose-treated group (G4) showed irregular thyroid follicles with an apparent increase in the follicular diameter and increase in the heights of the lining cells (Figures 3A and 4A). The follicles were disrupted and depleted and with vacuolated colloid (Figures 3B and 4B). Signs of hyperactivity were observed in most of the follicles (Figures 3C and 4B). Many of the thyroid follicles were obliterated due to the noticeable highly cellular hyperplasia of the follicular and interfollicular cells making papillary growth (Figure 3C). The presence of hyperchromatic nuclei characterized the hyperplastic cells and accompanied by nuclear changes in size and shape (Figures $3 \mathrm{~B}$ and $4 \mathrm{C}$ ). The lumina of the follicles were excessively filled with vacuolated thyroglobulin and formation of the papillary structure due to the hyperplasia of the epithelial cells was seen (Figure 4C). Severe bleeding and congestion of interfollicular capillaries were markedly observed (Figure 4B); especially in the tissues of the high dose of spirulina-treated group G4 (Figure 4B).

Slight improvement in the architecture of the thyroid gland tissues was observed in PTU+ Spirulina treated groups (G5 and G6) (Figures 5 and 6). Less hyperplastic activity in the variable-sized thyroid follicles, in addition to partially filled colloid, were observed (Figures 5A and 6A). Some follicles uniformly appeared lined with cuboidal cells, and others were lined with low columnar cells (Figures 5B and 6B). The vacuolated follicular cells have 
become less than that appeared in the Spirulina treated group (Figure 5C). Typical rounded thyroid follicles were more or less restored (Figure 5B). Also, the thyroglobulin has become more homogeneous and filled the follicular lumina of the thyroid tissue (Figure 6B). Also, the disappearance of the bleeding and the high congestion of the blood capillaries in the gland tissues, especially in the tissues of the high dose of Spirulina and PTU treated group were recorded (G6) (Figure 6B).

\section{Immunohistochemical results}

The immunohistochemical results revealed the negative expression of kI-67 in the nuclei of the follicular epithelial cells in the tissues of the thyroid gland of the control group (G1) (Figure 7A). Also, very weak KI-67 immunoreactivity was shown in thyroid gland sections of the PTU treated group (G2) (Figure 7B).

There was no KI-67 reaction observed in the sections of the thyroid gland of treated rats with both low and high doses of Spirulina (G3 and G4) (Figures 8A and 8B), respectively. On the other hand, nuclei of the epithelial cells lining the thyroid follicles of groups (PTU+ Spirulina) (G5 and G6) revealed weak to moderate KI-67 expression (Figures 9A and 9B) in comparison with both the control group (Figure 1A) and hypothyroidism (PTU) group (G2) (Figure 2B).

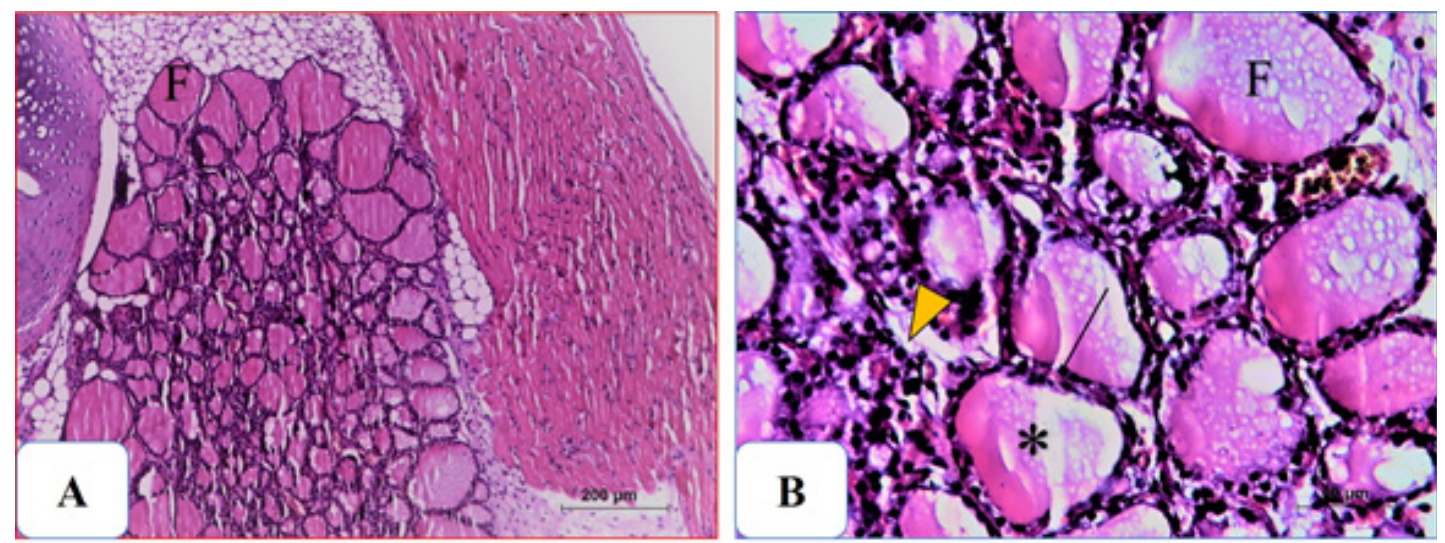

Fig. 1: Photomicrographs of sections of thyroid gland tissue of control rats G1stained with HxandE

(A)Various sized normal rounded follicles showing the follicles (F).

(B) The follicles are lined by simple low cuboidal cells (arrow) with round nuclei. The lumena of the central follicles are filled with homogeneous acidophilic structureless colloid having peripheral minute vacuolation $(*)$. In between the follicles lie the groups of interfollicular cells (arrow-head).
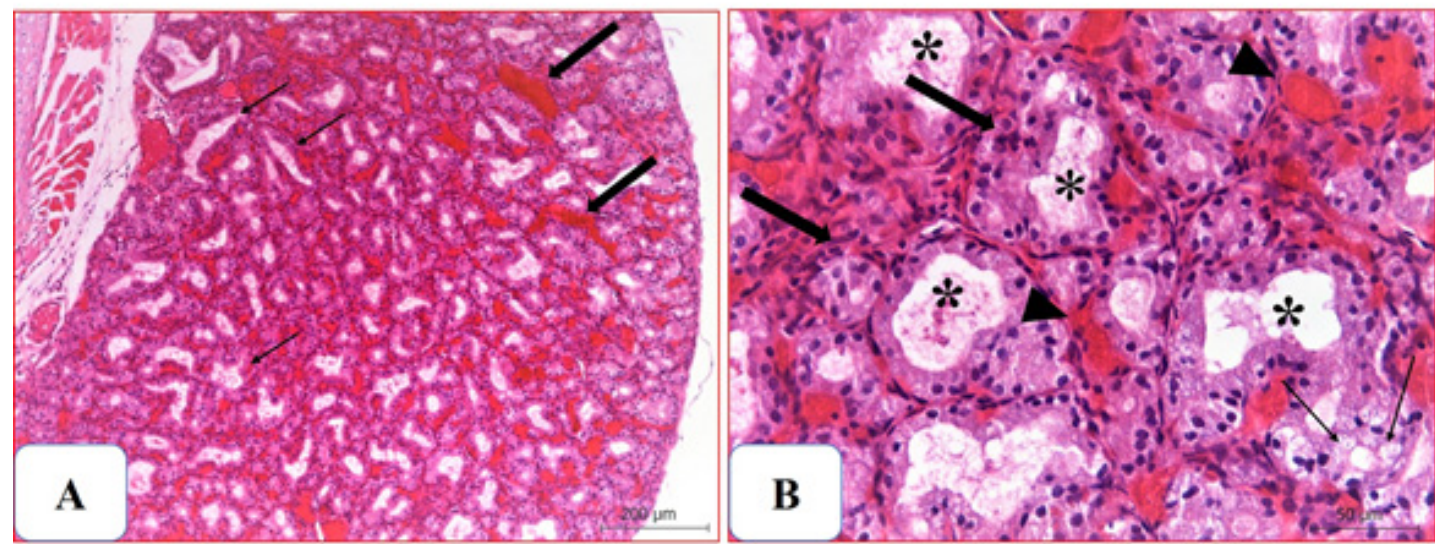

Fig. 2: Photomicrographs of sections of thyroid gland tissue of hypothyroidism (PTU)G2 stained with HxandE.

(A)The disorganization of thyroid follicles appears as irregular follicular wall (thin arrows) and highly congested blood capillaries taking the red colour (thick arrows).

(B)The disorganized thyroid follicles show depletion of the colloid and hence vacuolation of the lumena $(*)$, hyperchromatic nuclei and cytoplasmic vacuolation of the interfollicular cells (thin arrows). In addition to hyperplasia of the cuboidal lining of the thyroid follicles (thick arrows). 

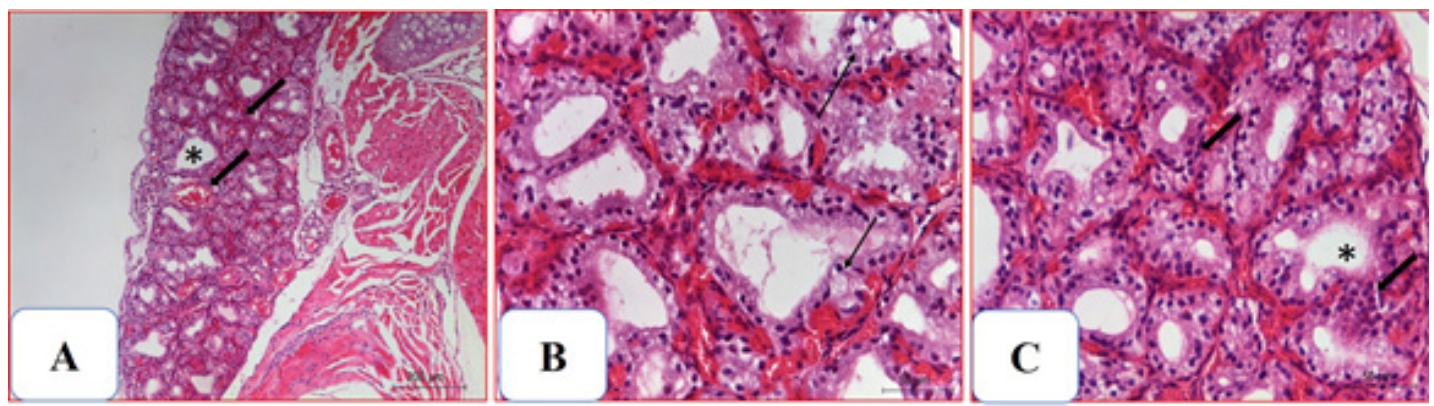

Fig. 3: Photomicrographs of sections of thyroid gland tissue from rats treated with low dose of Spirulina (G3) stained with HxandE showing : (A) Disrupted irregular thyroid follicles devoid of the colloid $(*)$.

(B) Cytoplasmic vacuolation of some follicular cells (arrows)

(C)The thyroid follicles showing free of the colloidal substance $\left(^{*}\right)$ and marked obliteration of some follicles due to hyperplasia of interfollicular cells with marked hyperchromatic nuclei (arrows), congested blood capillaries in between the follicles and bleeding at most of the blood capillaries (thick arrows).
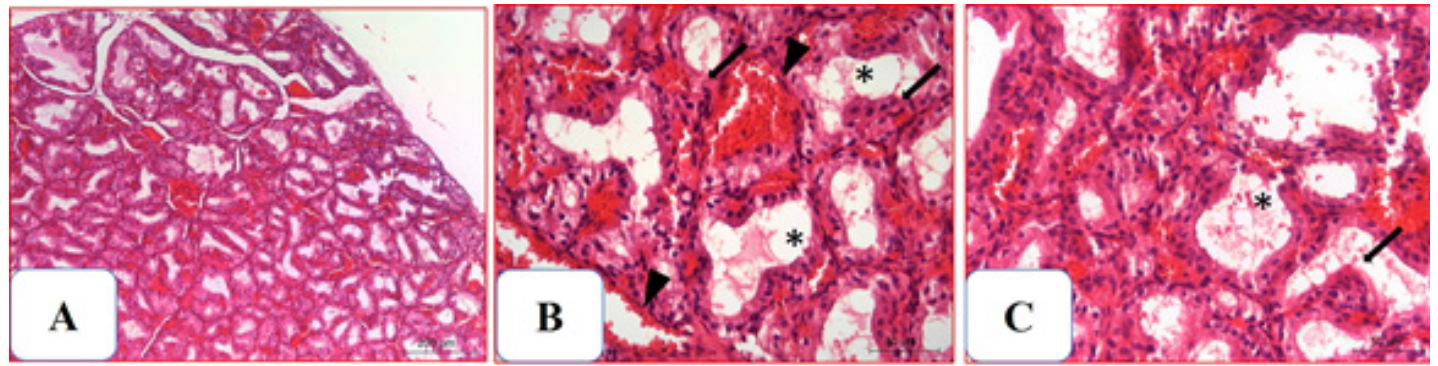

Fig. 4: Photomicrographs of sections of thyroid gland tissue from rats treated with high dose of Spirulina (G4) stained with HxandE showing :

(A)Loss of the gland architecture and much of the follicles become irregular in size and shape, widening of the interfollicular space and congestion of the blood capillaries.

(B) Asymmetrical follicles with traces of lytic globulin (*), existence of hyperplasia and hyperchromatic nuclei of the cuboidal/columnar lining cells (arrows) and severe hemorrhage in between the follicles (arrowheads).

(C) Marked hyperplasia of the follicular and interfollicular cells making a papillary form (arrows); accompanied by nuclear changes in size and shape, the lumina of the follicles are excessively vacuolated with proteolytic thyroglobulin $(*)$.
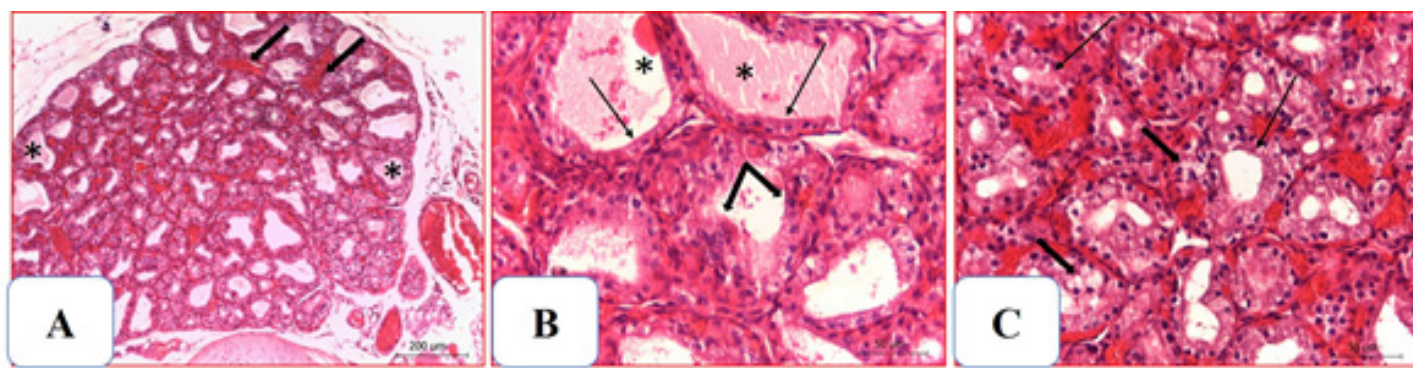

Fig. 5: Photomicrographs of sections of thyroid gland tissue from rats treated with PTU+ low dose of Spirulina (G5) stained with HxandE showing :

(A) Existence of partial recovering follicles and appearance of distended peripheral follicles with pale colloid $(*)$, while other follicles are small and involuted. The congestion of interfollicular capillaries still markedly observed (thick arrow). (B) Follicles lining with one layer of cuboidal cells (thin arrows) and lumina filled with acidophilic colloid with peripheral vacuolation $(*)$. Some follicles with thick walls due to hyperplasia of the cuboidal cells containing hyperchromatic nuclei (thick arrows). (C) Appearance of more or less normal rounded follicles (thin arrows) with narrow lumen and traces of the colloid also, the cytoplasmic vacuolation of the epithelial lining cells (thick arrows), while the congested blood capillaries are still apparent in the tissue.
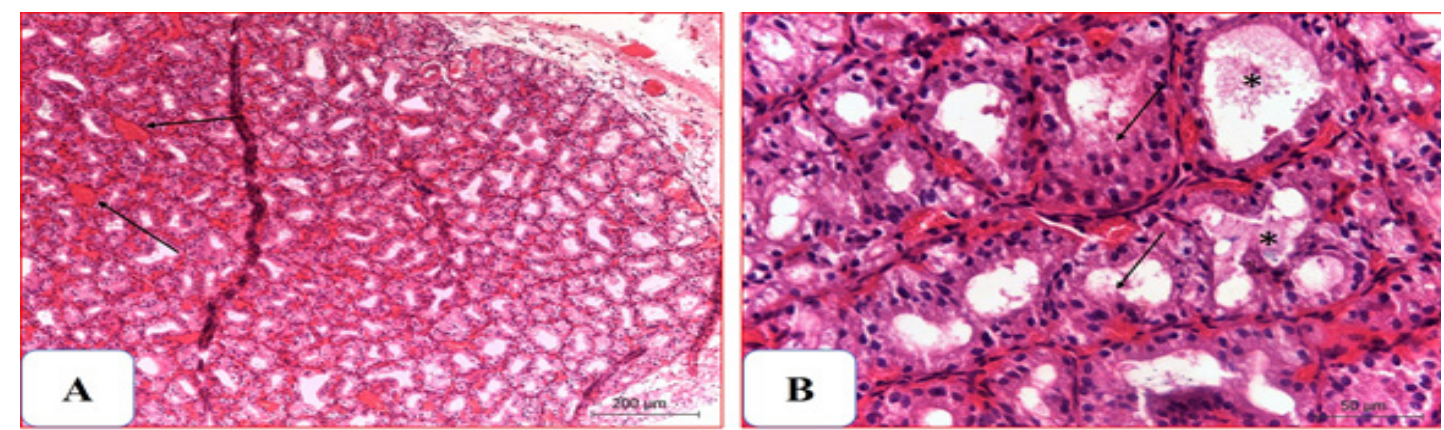

Fig. 6: Photomicrographs of sections of the thyroid gland of rats treated with PTU+ high dose Spirulina ( G6) stained with HxandE showing : (A) Gland tissue architecture is more or less normal, the peripheral follicles appear more distended than the central ones, but meager quantities of thyroglobulin are obvious. The intense congestion is remarkable in the inner tissue areas (arrow). (B) Several follicles with few acidophilic thyroglobulin $(*)$ but most of them show marked cellular hyperplasia at the wall (arrows) and less congestion. Most of the epithelial cells' nuclei appear normal in size but still hyperchromatic. 

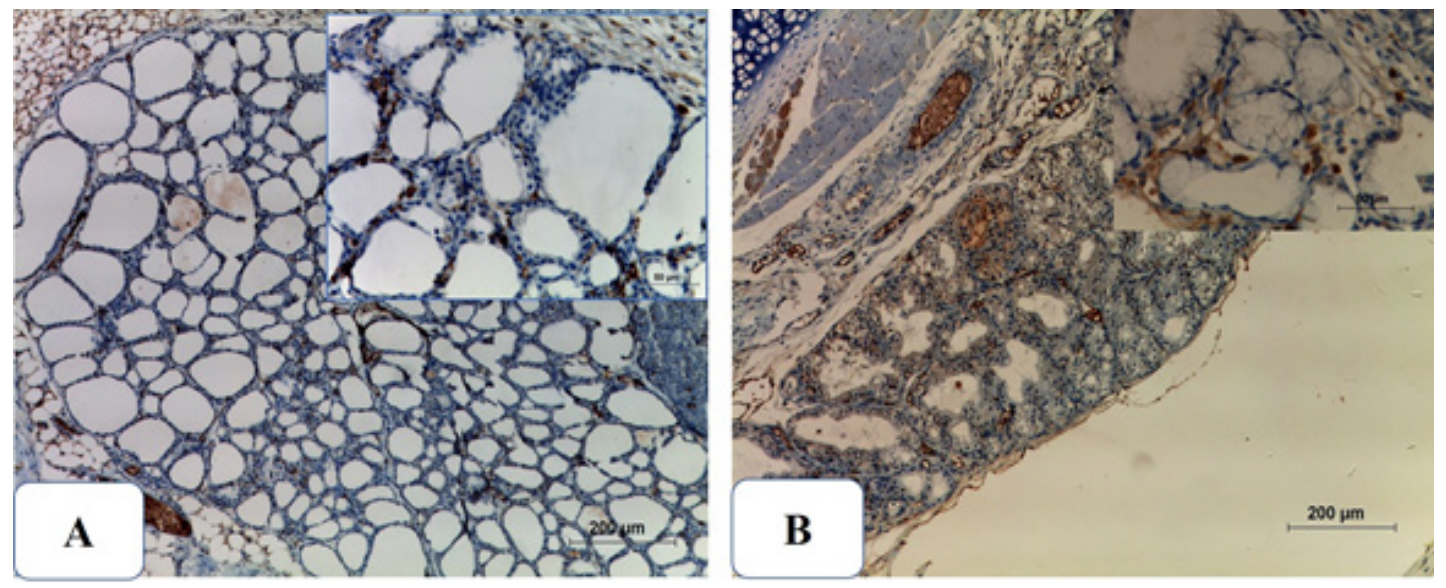

Fig. 7: Photomicrographs of immunohistochemical determination of KI-67 protein a cellular marker for proliferation.in the thyroid gland tissue. (A)Tissues of G1 showing negative immunostaining for $\mathrm{KI}-67$ and counterstained with Hematoxylin and Eosin stain. (B)Tissues of propylthiouracil G2 showing shallow nuclear immunolabelling expression for KI-67; most of the expression is confined to the interfollicular cells.
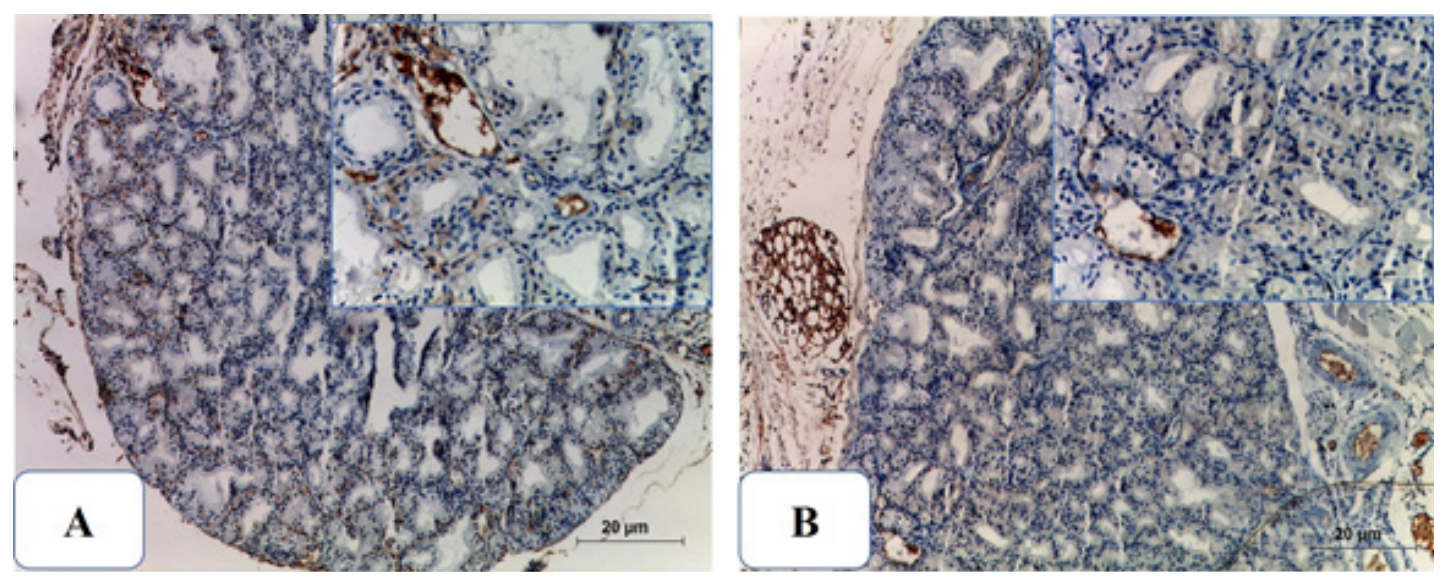

Fig. 8: Photomicrographs of immunohistochemical determination of KI-67 in the thyroid gland tissue.

(A)Tissues of G3 and (B) tissues of G4 showing negatively stained nuclei of the hyperplastic follicular cells.
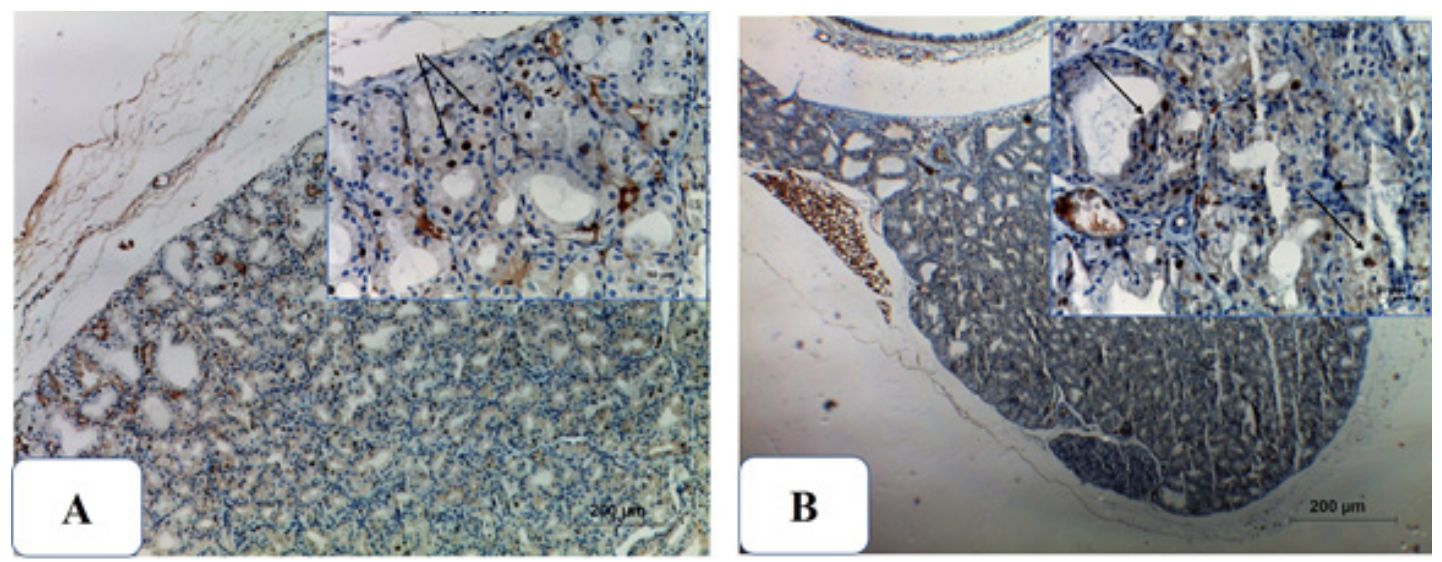

Fig. 9: Photomicrographs of immunohistochemical determination of KI-67 in the thyroid gland tissue.

(A)Thyroid tissue of G5 and (B) tissues of G6 are showing mild to moderate expression for KI-67 immunolabelling in some nuclei (arrows). 
Table 1: The effect of Spirulina on body weight gain $\%$ in the proposed studied groups

\begin{tabular}{|c|c|c|c|c|c|c|}
\hline & Control group & PTU group & SP-500 group & SP-1000 group & PTU+SP-500 group & PTU+SP-1000 group \\
\hline Body weight gain(\%) & $57.6 \pm 1.25$ & $47.2 \pm 2.08^{* *}$ & $20.6 \pm 1.08^{* * *}$ & $15.6 \pm 1.03^{* * *}$ & $27.4 \pm 1.77^{\text {抹 }}$ & $10.2 \pm 1.46^{\text {绷 }}$ \\
\hline
\end{tabular}

Seven rats per group

Values are expressed as means $\pm \operatorname{SEM}(n=7 / G)$

* indicates the significant difference of SP-treated groups and PTU-group vs. the control group ${ }^{* *} p<0.01,{ }^{* * *} p<0.001$.

\# indicates the significant difference of SP-treated groups vs. the PTU group \#\#\# $p<0.001$.

Table 2: The effect of Spirulina on T3,T4 and TSH in the proposed studied groups

\begin{tabular}{|c|c|c|c|c|c|c|}
\hline & Control group & PTU group & SP-500 group & SP-1000 group & PTU+SP-500 group & PTU+SP-1000 group \\
\hline $\mathrm{T} 3(\mathrm{ng} / \mathrm{dl})$ & $84.4 \pm 3.69$ & $47.2 \pm 2.13^{* * * *}$ & $83.6 \pm 1.43$ & $87.0 \pm 2.19$ & $49.8 \pm 1.77$ & $52.0 \pm 1.26$ \\
\hline $\mathrm{T} 4(\mu \mathrm{g} / \mathrm{dl})$ & $6.26 \pm 0.28$ & $5.2 \pm 0.11^{* *}$ & $6.7 \pm 0.5$ & $7.08 \pm 0.63$ & $5.54 \pm 0.23$ & $5.76 \pm 0.33$ \\
\hline $\mathrm{TSH}(\mu \mathrm{IU} / \mathrm{ml})$ & $0.396 \pm 0.02$ & $0.71 \pm 0.04^{* * *}$ & $0.35 \pm 0.16$ & $0.32 \pm 0.04$ & $0.65 \pm 0.04$ & $0.62 \pm 0.02$ \\
\hline
\end{tabular}

Seven rats per group

Values are expressed as means \pm SEM $(n=7 / G)$.

$*$ indicates the significant difference of SP-treated groups and PTU-group vs. the control group $* * p<0.01, * * * p<0.001$.

Table 3: The effect of Spirulina on thyroid follicular diameter and epithelial height in the proposed studied groups

\begin{tabular}{|c|c|c|c|c|c|c|}
\hline & Control group & PTU group & SP-500 group & SP-1000 group & PTU+SP-500 group & PTU+SP-1000 group \\
\hline Folliculardiameter $(\mu \mathrm{m})$ & $51.67 \pm 2.93$ & $66.46 \pm 3.37^{* *}$ & $60.21 \pm 1.89^{*}$ & $64.17 \pm 2.86^{*}$ & $65.13 \pm 2.01$ & $65.83 \pm 1.15$ \\
\hline Epithelial height $(\mu \mathrm{m})$ & $10.83 \pm 0.53$ & $16.88 \pm 0.62^{* * * *}$ & $12.08 \pm 0.42$ & $13.75 \pm 0.56^{* *}$ & $16.25 \pm 0.46$ & $16.04 \pm 0.5$ \\
\hline
\end{tabular}

Seven rats per group

Values are expressed as means \pm SEM $(\mathrm{N}=7 / \mathrm{G})$.

* indicates the significant difference of SP-treated groups and PTU group vs. the control group * $p<0.05, * * p<0.01, * * * p<0.001$.

\section{DISCUSSION}

The thyroidgland is an endocrine gland that is responsible for the production, storage, and release of thyroid hormones triiodothyronine (T3) and thyroxin (T4). These hormones are essential for cell growth and development ${ }^{[31]}$. One of the thyroid disorders is hypothyroidism which is defined as a deficiency in thyroid hormones production as a result of dysfunction of the thyroid gland leading to disruption of the synthesis and secretion of hormones ${ }^{[32]}$.

The current investigation aimed to evaluate the hormonal, histological, and immunohistochemical changes in hypothyroid-model, also to assess whether Spirulina has potential ameliorating effects against hypothyroidism. The present work designed to be carried out with several experimental animals that was enough to get real and confirmed results. Whereas, the various articles in the fields of applied toxicological developmental and pharmaceutical work caring to use enough animals to expect the primary outcomes.

One of the most important observations was the decrease in body weight gain in rats treated with PTU compared to the control group, as previously reported in various studies ${ }^{[33]}$. This decrease could be attributed to the decline in levels of T3 and T4 that have a potential effect on the metabolism and homeostasis in animal body. Also, certain study referred to the previous result of impairment in energy metabolic processes along with a decrease in the basal metabolic rate ${ }^{[34]}$. Moreover, a significant decline in the body weight gain was observed in the rats that have been treated with the different doses of Spirulina compared to those of control rats.

This finding is supported by the results of earlier studies, which reported that treatment with Spirulina leads to the suppression of body weight gain and body mass index ${ }^{[35-38]}$. Also, this result might be attributed to the loss of appetite during the experiment. This interpretation is supported by Mazokopakis et al. (2014b), who reported that Spirulina is rich in phenylalanine, a potent releaser of cholecystokinin that affects the brain's appetite center, which in turn suppress the body weight. On the other hand, the reduction effect of Spirulina on body weight is due to its antioxidant properties through decreasing the lipase, suppression of food intake, and the regulation effect on lipid metabolites ${ }^{[39 a n d 40]}$.

Biochemically, PTU induced the hypothyroidism that is reflected in the recorded hormonal levels of $\mathrm{T} 3, \mathrm{~T} 4$, and TSH. A significant decrease in the serum T3 and T4 concentration was observed in the statistical analysis; also, the TSH recorded a significant increase compared to the control values. The present results agreed with several previous studies ${ }^{[4 \operatorname{land} 42]}$. The principle of the PTU action mechanism depends on that the thyroid peroxidase enzyme 
controls T4 production that inhibits the secretion of the thyroid hormones and inhibits the conversion of the active form of T4, T3 in peripheral tissues ${ }^{[43 a n d 44]}$.

In the current study, the histological findings of thyroid gland confirmed the hypothyroid status such as hyperplasia signs, cellular cytoplasmic vacuolation, dilated congested blood capillaries, and the increase in the height of the follicular cells, besides the increase in the diameters of the thyroid follicles. In addition, degenerated and vacuolated thyroglobulin masses were shown in the follicular cells and the interfollicular cells. Similar results were described by Underwood et al., (2009) ${ }^{[45]}$.

The cellular cytoplasmic vacuolation could be due to fluid accumulation and glandular overstimulation, or due to hydropic and vacuolar degeneration ${ }^{[46]}$. Furtherly, the observed increase in follicular epithelium height that was confirmed statistically compared with the control group may be due to the hyperactivity of the cells, which were stimulated by the high level of the TSH hormone. Similar results have been previously reported by other researchers ${ }^{[47]}$. Also, the observed increase in the height of the cells can be explained by the increased functional capacity that resulted from the increased substantive demand. Cellular hyperplasia can be attributed to the stimulation of resting cells to enter the cell cycle (G1) to divide in response to the changed endocrine milieu and increased functional demand for injury ${ }^{[48]}$.

In our study, the increased TSH levels in hypothyroidism model were in agreement with Standring (2008) ${ }^{[49]}$ who reported that prolonged high levels of circulating TSH induces the follicular cell hyperplasia and increase the stromal vascularity. Moreover, Ramsden $(2000)^{[50]}$ reported that the increase of TSH causes the vascular endothelial growth factor produced in the thyroid, and this factor is a potent angiogenic protein that is responsible for the vascularization.

In the present study, the PTU-treated group showed peripheral colloidal degeneration and vacuolation with most of the thyroid follicles. Since PTU does not affect the iodinated thyroglobulin already stored in the gland ${ }^{[51]}$, so it could be suggested that follicular cells increase their activity in taking up and releasing thyroid hormones into the circulation to compensate for the increased demand ${ }^{[52]}$.

Also, the current results reported insignificant changes in the hormonal levels in the treated rats with the low or high doses of Spirulina, while remarkable histopathological changes in the thyroid sections in a dose-dependent manner were noticed compared to control group. As far as the authors are aware, no previous reported studies were carried out on the direct or indirect effects of Spirulina on the thyroid gland.

The current study reported that the co-administration of PTU-group with Spirulina resulted in an insignificant increase in T3 and T4 levels and negligible decrease in the TSH level. Also, to a slight improvement in the thyroid histological structure compared to the PTU-group. It could be interpreting that the histopathological changes have resulted from hyper-stimulation of TSH in the PTU group, and these changes also slightly improved by the limited decrease in TSH. These slight improvements appeared as a reduction in the congestion of blood capillaries and little restoration of thyroglobulin in the follicles. So, Spirulina cannot ameliorate the impact of PTU completely. The proposed results in this work are in a disagreement with a previous study reported by Assoc (2002) ${ }^{[53]}$ who recorded that Spirulina is a nutritional and therapeutic supplement giving rise healthy markers and good vital indicators on the body's homeostasis. Moreover, Liu et al., $\left(2006^{[54]}\right.$ reported that Spirulina had a positive effect on the hematopoietic recovery and related cytokines in mice. Also, Chu et al., $(2010)^{[55]}$ verified that the aqueous extract from Spirulina has a protective effect against cell death.

Based on the few existing studies, there are beneficial allergic and immunological effects of consumption of bluegreen algae Spirulina ${ }^{[56 a n d 57]}$. In the proposed work, the cells stained with KI-67 antigen nuclear protein for the cellular proliferation showed some positive cells in the tissues of PTU+Spirulina (500 and $1000 \mathrm{mg} / \mathrm{kg} /$ body wt.) treated groups while the tissues of Spirulina' groups alone revealed negative expression for KI-67 marker. Also, the existence of hyperplasia in the tissues due to the hyperactivity of the cells could be explained by various studies that mentioned the possibility of transformation of the hyperplasia into benign or malignant tumors depending upon the physiological factors and responses ${ }^{[58]}$. Also, according to the reactions due to the excess of hormones or growth factors could be responsible for the stimuli ${ }^{[59]}$. Moreover, the pathologic hyperplastic cells may be changed into neoplastic cells due to genetic aberrations which control the proliferated cells in a non-physiological way, and they have not a response to the normal stimuli ${ }^{[60,61 \text { and } 62]}$.

More recorded studies reported that the Spirulina could be used within the drugs to reduce their side effects of the drugs on the metabolism and to increase the efficiency of the immune system of the body ${ }^{[63]}$. It has been well documented that Spirulina has anti-inflammatory properties, through inhibiting the release of histamine from mast cell-mediated allergic reactions ${ }^{[64 a n d 65]}$. So, in the present study, it can be concluded that the reduction of bleeding and decrease of congestion in the blood capillaries in the thyroid gland in PTU+ Spirulina treated groups is due to the anti-inflammatory effect of the Spirulina.

The signs of improvement in thyroid tissue of rats treated by PTU and Spirulina might be due to the iodide content of the Spirulina. Moreover, the iodine intake actively plays a vital role in the functions and performance of the gland, as well as keeping the metabolism and homeostasis stable and in a normal manner ${ }^{[66]}$. Also, it was reported that the blue-green algae Spirulina has antioxidant and antiapoptotic properties, which make it reduces the cell injuries, improve the enzyme functions, and prevent the oxidation process in the body. Also, its content of vitamins, 
superoxide dismutase, minerals and the $\mathrm{C}$ phycocyanin which is a protein-bound pigment found in Spirulina, inhibits oxalate-mediated lipid peroxidation and prevents injury in many tissues ${ }^{\left[{ }^{[7 a n d} 68\right]}$.

In conclusion, the treatment of the induced hypothyroid rat with the two doses of Spirulina resulted in slight improvement and restoration of the thyroid histological architecture and hormonal levels. On the contrary, treatment with Spirulina alone resulted in remarkable high hyperplasia as a cellular change at the two studied experimental doses. In the current study, both selected low and high doses of Spirulina that have been chosen were different than those recorded in other various experimental studies. Moreover, the impact of Spirulina on the hypothyroid model has a slight ameliorating effect on the histological structure, but care should be taken because the hyperplastic cells can be transformed into benign or malignant tumors. This assumption is aided by the appearance of some positively expressed nuclei with the KI-67 marker of proliferation. So, caution should be used in extrapolating these results to the human being. Additionally, may be the application of the present study with more long terms and different doses of Spirulina give different results.

\section{CONFLICT OF INTEREST}

There are no conflict of interest.

\section{FUNDING}

The authors declare that they have no known competing financial interests or personal relationships that could have appeared to influence the work reported in this paper.

\section{REFERENCES}

1. Stathatos, Nikolaos. "Anatomy and physiology of the thyroid gland." The Thyroid and Its Diseases. Springer, Cham, 2019. 3-12.

2. Rajab, Njia M. Ali, Mirela Ukropina, and Maja CakicMilosevic. "Histological and ultrastructural alterations of rat thyroid gland after short-term treatment with high doses of thyroid hormones." Saudi journal of biological sciences 24.6 (2017): 1117-1125.

3. Bianco, Antonio C., and Elizabeth A. McAninch. "The role of thyroid hormone and brown adipose tissue in energy homoeostasis." The lancet diabetes and endocrinology 1.3 (2013): 250-258

4. Boelaert, K., and J. A. Franklyn. "Thyroid hormone in health and disease." Journal of Endocrinology 187.1 (2005): 1-15.

5. Fatourechi, Vahab. "Subclinical hypothyroidism: an update for primary care physicians." Mayo Clinic Proceedings. Vol. 84. No. 1. Elsevier, 2009.

6. Lin, Xingsheng, Songjing Shi, and Songchang Shi. "Sepsis leads to thyroid impairment and dysfunction in rat model." Tissue and Cell 48.5 (2016): 511-515.
7. Roelfsema, Ferdinand, et al. "Regulatory aspects of the human hypothalamus-pituitary-thyroid axis." Best Practice and Research Clinical Endocrinology and Metabolism 31.5 (2017): 487-503.

8. Wang, Yuwei, et al. "A comparison of the thyroid disruption induced by decabrominated diphenyl ethers (BDE-209) and decabromodiphenyl ethane (DBDPE) in rats." Ecotoxicology and environmental safety 174 (2019): 224-235.

9. Ahmed, Osama M., et al. "Thyroid hormones states and brain development interactions." International Journal of Developmental Neuroscience 26.2 (2008): 147-209.

10. Salazar, Paulina, et al. "Induction of hypothyroidism during early postnatal stages triggers a decrease in cognitive performance by decreasing hippocampal synaptic plasticity." Biochimica et Biophysica Acta (BBA)-Molecular Basis of Disease 1863.4 (2017): 870-883.Biophysica Acta (BBA)-Molecular Basis of Disease. 1863(4),870-883.

11. Tousson, Ehab, et al. "The ameliorating role of folic acid in rat hippocampus after propylthiouracil-induced hypothyroidism." Biomedicine and Aging Pathology 2.3 (2012): 104-110.

12. Humes, H. David, Herbert L. DuPont, and Laurence B Gardner, eds. Kelley's textbook of internal medicine. Lippincott Williams and Wilkins, 2000.

13. Martín-Lacave, Inés, et al. "C cells evolve at the same rhythm as follicular cells when thyroidal status changes in rats." Journal of anatomy 214.3 (2009): 301-309.

14. Sener, G., et al. "Propylthiouracil-induced hypothyroidism protects ionizing radiationinduced multiple organ damage in rats." Journal of endocrinology 189.2 (2006): 257-269.

15. Zbucki, Robert Lukasz, et al. "Alteration of parafollicular $(\mathrm{C})$ cells activity in the experimental model of hypothyroidism in rats." Folia histochemica et cytobiologica 45.2 (2007): 115-121.

16. Zoeller, R. Thomas, and Kevin M. Crofton. "Mode of action: developmental thyroid hormone insufficiency-neurological abnormalities resulting from exposure to propylthiouracil." Critical reviews in toxicology 35.8-9 (2005): 771-781.

17. El-Sheekh, Mostafa Mohamed, Saied Mohamed Hamad, and Mahmoud Gomaa. "Protective effects of Spirulina on the liver function and hyperlipidemia of rats and human." Brazilian Archives of Biology and Technology 57.1 (2014): 77-86.

18. Fu, Xiang, et al. "The protective effects of seleniumenriched Spirulina platensis on chronic alcoholinduced liver injury in mice." Food and function 9.6 (2018): 3155-3165. 
19. Ismail, Md, et al. "Effect of spirulina intervention on oxidative stress, antioxidant status, and lipid profile in chronic obstructive pulmonary disease patients." BioMed research international 2015 (2015).

20. Mahmoud, Yomna I., and Eman A. Abd El-Ghffar. "Spirulina ameliorates aspirin-induced gastric ulcer in albino mice by alleviating oxidative stress and inflammation." Biomedicine and Pharmacotherapy 109 (2019): 314-321.

21. Serban, Maria-Corina, et al. "A systematic review and meta-analysis of the impact of Spirulina supplementation on plasma lipid concentrations." Clinical Nutrition 35.4 (2016): 842-851.

22. Lu, Hsueh-Kuan, et al. "Preventive effects of Spirulina platensis on skeletal muscle damage under exerciseinduced oxidative stress." European journal of applied physiology 98.2 (2006): 220.

23. Ovando, Claudia Anahite, et al. "Functional properties and health benefits of bioactive peptides derived from Spirulina: A review." Food reviews international 34.1 (2018): 34-51.

24. Basha, Osama M., et al. "C-Phycocyanin inhibits cell proliferation and may induce apoptosis in human HepG2 cells." Egypt J Immunol 15.2 (2008): 161-167.

25. El-Desoky, Gaber E., et al. "Improvement of mercuric chloride-induced testis injuries and sperm quality deteriorations by Spirulina platensis in rats." PLoS One 8.3 (2013): e59177.

26. Karadeniz, Ali, Mustafa Cemek, and Nejdet Simsek. "The effects of Panax ginseng and Spirulina platensis on hepatotoxicity induced by cadmium in rats." Ecotoxicology and Environmental Safety 72, no. 1 (2009): 231-235.

27. Khan, Zakir, Pratiksha Bhadouria, and P. S. Bisen. "Nutritional and therapeutic potential of Spirulina." Current pharmaceutical biotechnology 6.5 (2005): 373-379.

28. Paniagua-Castro, Norma, et al. "Spirulina(Arthrospira) protects against cadmium-induced teratogenic damage in mice." Journal of medicinal food 14.4 (2011): 398404.

29. Ponce-Canchihuamán, Johny C., et al. "Protective effects of Spirulina maxima on hyperlipidemia and oxidative-stress induced by lead acetate in the liver and kidney." Lipids in health and disease 9.1 (2010): 35.

30. Shabana E., Gabr M., Moussa H., chemistry EE.SF. undefined, n.d. Biochemical composition and antioxidant activities of Arthrospira (Spirulina) platensis in response to gamma irradiation. Food Chemistry. 214 (2017): 550-555.

31. Vargas-Uricoechea, Hernando, and Anilza BoneloPerdomo. "Thyroid dysfunction and heart failure: mechanisms and associations." Current heart failure reports 14.1 (2017): 48-58.

32. Goldman L. and Ausiello DA eds. Cecil medicine. (2008). (pp. 1212-1216). Philadelphia: Saunders Elsevier.

33. Badauê-Passos, D. Jr, et al. "Effect of losartan on sodium appetite of hypothyroid rats subjected to water and sodium depletion and water, sodium and food deprivation." Experimental physiology 86.5 (2001): 621-628.

34. Elkalawy, Seham AM, et al. "Histological and immunohistochemical study of the effect of experimentally induced hypothyroidism on the thyroid gland and bone of male albino rats." Egyptian Journal of Histology 36.1 (2013): 92-102.

35. Mazokopakis, Elias E., Ioannis K. Starakis, Maria G. Papadomanolaki, Niki G. Mavroeidi, and Emmanuel S. Ganotakis. "The hypolipidaemic effects of Spirulina (Arthrospira platensis) supplementation in a Cretan population: a prospective study." Journal of the Science of Food and Agriculture 94, no. 3 (2014): 432-437.

36. Szulinska, M., et al. "Spirulina maxima improves insulin sensitivity, lipid profile, and total antioxidant status in obese patients with well-treated hypertension: A randomized double-blind placebo-controlled study." Eur Rev Med Pharmacol Sci21.10 (2017): 2473-2481.

37. Zeinalian, Reihaneh, et al. "The effects of Spirulina Platensis on anthropometric indices, appetite, lipid profile and serum vascular endothelial growth factor (VEGF) in obese individuals: a randomized double blinded placebo controlled trial." BMC complementary and alternative medicine 17.1 (2017): 225.

38. Yousefi, Reyhaneh, Atoosa Saidpour, and Azadeh Mottaghi. "The effects of Spirulina supplementation on metabolic syndrome components, its liver manifestation and related inflammatory markers: A systematic review." Complementary therapies in medicine (2018).

39. Winter, Frank, et al. "The effect of Arthrospira platensis capsules on CD4 T-Cells and antioxidative capacity in a randomized pilot study of adult women infected with human immunodeficiency virus not under HAART in Yaoundé, Cameroon." Nutrients 6.7 (2014): 2973-2986.

40. Hassan, Hanaa A., and Nermin E. El-Gharib. "Obesity and clinical riskiness relationship: therapeutic management by dietary antioxidant supplementation - a review." Applied biochemistry and biotechnology 176.3 (2015): 647-669.

41. Bhanja, S., and G. B. N. Chainy. "PTU-induced hypothyroidism modulates antioxidant defence status in the developing cerebellum." International Journal of Developmental Neuroscience 28.3 (2010): 251-262. 
42. Yu, Haiying, et al. "Thyroid status influence on adiponectin, acylation stimulating protein (ASP) and complement $\mathrm{C} 3$ in hyperthyroid and hypothyroid subjects." Nutrition and metabolism 3.1 (2006): 13.

43. Axelstad, Marta, et al. "Developmental neurotoxicity of propylthiouracil (PTU) in rats: relationship between transient hypothyroxinemia during development and long-lasting behavioural and functional changes." Toxicology and applied pharmacology 232.1 (2008): $1-13$.

44. Burch, Henry, and David Cooper. "Anniversary review: 70 years of Antithyroid Drug Therapy." European Journal of Endocrinology 1.aop (2018).

45. Underwood, James CE, and Simon S. Cross. General and Systematic Pathology, International Edition E-Book: with STUDENT CONSULT Access. Elsevier Health Sciences, 2009.

46. Kumar, Vinay, et al. "Robbins Basic Pathology . Saunders Elsevier." NY, USA (2007): 516-522.

47. Ferreira, E., et al. "Model of induction of thyroid dysfunctions in adult female mice." Arquivo Brasileiro de Medicina Veterinária e Zootecnia 59.5 (2007): 1245-1249.

48. Rubin, Raphael, David S. Strayer, and Emanuel Rubin, eds. Rubin's pathology: clinicopathologic foundations of medicine. Lippincott Williams and Wilkins, 2008.

49. Standring, Susan, et al. "Gray's anatomy: the anatomical basis of clinical practice." American Journal of Neuroradiology 26.10 (2005): 2703.

50. Ramsden JD.. Angiogenesis in the thyroid gland. J. Endocrinol. 166 (2000): 475-80.

51. Howland, Richard D., et al. Lippincott's illustrated reviews: Pharmacology. Philadelphia: Lippincott Williams and Wilkins, 2006.

52. Gartner, Leslie P., and James L. Hiatt. Color textbook of histology e-book. Elsevier Health Sciences, 2006.

53. Belay, Amha. "The potential application of Spirulina (Arthrospira) as a nutritional and therapeutic supplement in health management." J Am Nutraceutical Assoc 5 (2002): 27-48.

54. Liu, Xiao-mei, and Hong-quan Zhang. "Effect of spirulina platensis polysaccharide on hematopoietic recovery and related cytokines in mice with transplanted tumor treated by chemotherapy." Chinese Journal of Integrated Traditional and Western Medicine 8.2 (2002): 130-133.

55. Chu, Wan-Loy, et al. "Protective effect of aqueous extract from Spirulina platensis against cell death induced by free radicals." BMC complementary and alternative medicine 10.1 (2010): 53.
56. Qureshi, M. A., M. T. Kidd, and R. A. Ali. "Spirulina platensis extract enhances chicken macrophage functions after in vitro exposure." Journal of Nutritional Immunology 3.4 (1996): 35-45.

57. Qureshi, M. A., and R. A. Ali. "Spirulina platensis exposure enhances macrophage phagocytic function in cats." Immunopharmacology and immunotoxicology 18.3 (1996): 457-463.

58. Sembulingam, Kirma, and Prema Sembulingam. Essentials of medical physiology. JP Medical Ltd, 2012.

59. Kelly, Greg. "Peripheral metabolism of thyroid hormones: a review." Alternative medicine review 5.4 (2000): 306-306.

60. Guo, Zhenzhen, et al. "miR-196b inhibits cell migration and invasion through targeting MAP3K1 in hydatidiform mole." Biomedicine and Pharmacotherapy 113 (2019): 108760.

61. Kumar, V., Abul K. Abbas, and J. C. Aster. "Robbins Basic Pathology 9thEd." (2013): 48.

62. Zhao, Haiying, et al. "Expression of FOXC2, PinX1, Ki-67 and Cyclin D1 in cutaneous cell carcinoma." Oncology letters 14.1 (2017): 635-638.

63. Mosulishvili, L. M., et al. "Epithermal neutron activation analysis of Spirulina platensis biomass and extracted C-phycocianin and DNA." Journal of radioanalytical and nuclear chemistry 259.1 (2004): 41-45.

64. Mao, T. K., J. Van de Water, and M. Eric Gershwin. "Effects of a Spirulina-based dietary supplement on cytokine production from allergic rhinitis patients." Journal of Medicinal Food 8.1 (2005): 27-30.

65. Price Iii, Joseph A., Charles Sanny, and Dennis Shevlin. "Inhibition of mast cells by algae." Journal of medicinal food5.4 (2002): 205-210.

66. Frontasyeva, Marina V., et al. "Accumulation of trace elements by biological matrice of Spirulina platensis." Ecologi-cal Chemistry and Engineering S-Chemia i inzynieria ekologiczna S 16.3 (2009): 277-285.

67. Belay, Amha. "The potential application of Spirulina (Arthrospira) as a nutritional and therapeutic supplement in health management." JAm Nutraceutical Assoc 5 (2002): 27-48.

68. Yener, Nese Arzu, et al. "Effects of spirulina on cyclophosphamide-induced ovarian toxicity in rats: biochemical and histomorphometric evaluation of the ovary." Biochemistry research international 2013 (2013). 
الملخص العربى

\section{تأثير السبيرولينا على قصور الغدة الدرقية ـ المستحث بالبروبيل ثيويوراسيل

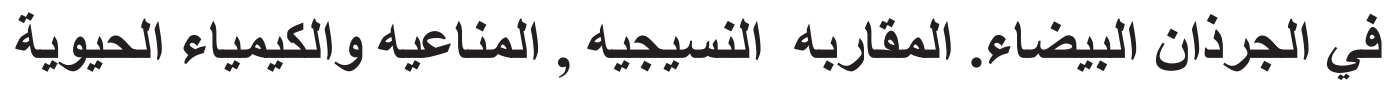 هاله جلال الطنطاوى وفاتن صبره أبو زيد قسم علم الحيوان، كلية العلوم، جامعة عين شمس، مصر}

الخلفية: الغدة الدرقية هي واحدة من الغدد الصماء الأساسية وتلعب دورا حيويا في عملية التمثيل الغذائي في الجسم. قصور الغدة الدرقية هو انخفاض في إنتاج هرمونات الغدة الدرقية ويؤدي إلى اختلال وظيفي في الغدة. السبيرولينا تستخدم كمضاد للأكسدة ومضاد للسكري ومضاد للسرطان ، ومن المفترض أن يكون مضادا لقصور الغدة الدرقية.

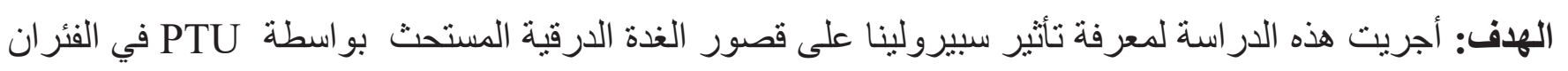
البيضاء.

المواد والطرق: تم تقسيم الفئران إلى ست مجموعات ، المجموعة الضابطة (G1) ، مجموعة قصور الغدة الدرقية

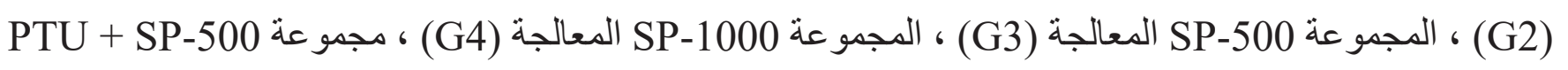
المعالجة (G5) ) ومجمو عة (GTU + SP-1000 المعالجة (G6) و (G) تم فحص الغدة الدرقية باستخدام الدر اسات الكيميائية الحيوية و النسيجية و المناعية. وكانت التجربه (G) لمدة 14 يوما. النتائج: ظهر انخفاض كبير في معدل اكتساب وزن الجسم في جميع الفئات مقارنة مع المجمو عه الضابطه. كما لوحظ ولئ كيميائيا انخفاض محسوس في مستويات هرمونات الغده الدرقيه T3, T4 في مجمو عة PTU مقارنة مع المجموعة فئة

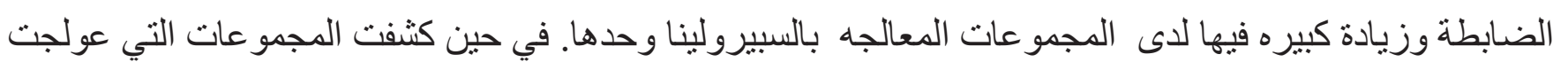

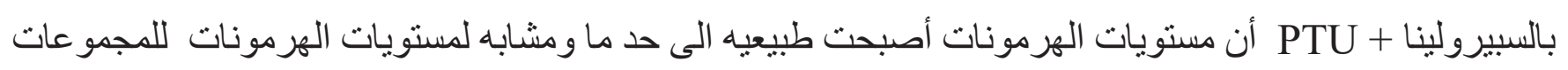
الضابطه ـ كذلك ظهرت تغير ات نسيجية مثل احتقان الثعير ات الدموية ، وتوسع حويصلات الغده ، و التنكس الفر اغي

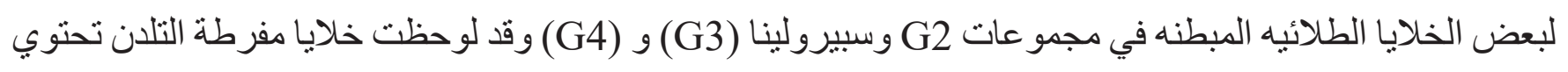
على نوى مفرطة كروماتية ، و ثنايروجلوبولين به فجوات ، وزيادة كبيرة في المرتفعات الظهارية و أقطار الحويصلات.

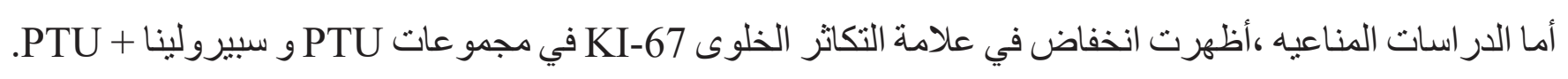
في حين تم تسجيل التعبير السلبي KI-67في مجمو عات المعامله بالسبيرولينا. الخلاصة: أدت المعامله بالسبيرولينا وحدها علامات فرط التكاثر الخلوى فى الغدة الدرقية ، ولكن لديها دور وقائي خفيف في قصور الغدة الدرقية المستحث بو اسطة PTU لذلك يجب توخي الحذر في استقر اء هذه النتائج لحالة الإنسان و إجر اء مزيد من الدر اسات في جر عات ومدد مختلفة. 